\title{
Developing Skills in Pre-School Age with Computer and Mobile Applications
}

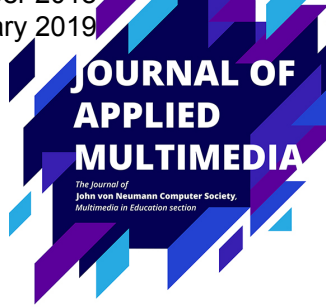

\section{Iskolakezdéshez szükséges képességek fejlesztése számítógépes és mobilalkalmazások segítségével}

\author{
Barbara Misják*, Antónia Berecz** \\ *Dennis Gabor Talent Point, Hungary, Budapest \\ ** Dennis Gabor College/Institute of Basic and Technical Sciences, Hungary, Budapest \\ *barbaramisjak@gmail.com, ${ }^{* *}$ berecz@gdf.hu
}

\begin{abstract}
The presentation focuses on introducing opportunities by multimedia for pre-school education. It aims to define what the term being school ready means, and also discusses the misunderstandings around the topic and the use of ICT tools in public education in Hungary and abroad. Finally, examples for mobile and computer applications developed for educational purposes are going to be represented.
\end{abstract}

Összefoglaló - Az előadás az óvodások iskola-előkésztéséhez használható multimédiás lehetőségekbe ad betekintést. Definiálja az iskolaérettséget, foglalkozik az iskolaérettséggel kapcsolatos félreértésekkel, az IKT eszközök közoktatásban való használatával hazánkban és külföldön. Végül példákat mutat képességfejlesztési lehetőségekre számítógépes és mobilalkalmazások segítségével.

Keywords: pre-school age, skills development, computer and mobile applications.

Kulcsszavak: iskolakezdés elötti korosztály, képességfejlesztés, számítógépes és mobilalkalmazások.

\section{INTRODUCTION}

Digital competencies have become basic skills which are essential beginning from childhood in education, and later for adults at job and by everyday routine. A few decades ago, no one would think for preschool children the use of touch screen is becoming evident, and for school age it is becoming natural to get almost all information available with a few clicks via internet. They are engaged by smart devices and mobile games day by day, which could have seemed to fit in science-fantastic stories some generations ago. Applications developed to prepare children for starting school through play are therefore popular and useful in the same time.

\section{CHILDREN'S INTO ACTIVITIES EMBEDDED LEARNING}

At birth, a baby's brain contains about100 billion neurons, but most of these have no connection to each other. For the age of 3, each neurons builds up to 10000 connections with other neurons. The combination of multiple learning strategies could help by building these new neural connections and could also increase the efficiency of developing new skills [1].
Why are children so easy to get engaged by learning with ICT $^{1}$ tools? Children's learning is the most effective, when they are learning through activities which are interesting for them [2]. While playing, the attention of a child is constantly alive. Toddlers are more likely to learn effectively when playing games. With interesting, colorful, mobile apps it is easier to keep their attention. On mobile devices, colorful, loud and spectacular games can be effectively applied for education. A great advantage of mobile devices against PCs or laptops, that kids are not tied to space when using them. By contrast, children often feel to be forced when learning from a book, and the pressure they are feeling because of this may cause the producing of stress hormones which have a negative impact on developing neural pathways [2].

Research has shown that sensory organs play an important role in learning, helping to derive energy, nourish and keep attention [2]. Mobile applications make it easy to exploit this help factor: by spectacular, colorful graphics could have an impact on the sight, by sound effects and pronouncing the instructions of a game stimulates the hearing. With gyroscopes and digital compasses, additional possibilities become available for promoting mobility.

\section{THE MEANING OF BEING SCHOOL READY}

There are plenty of misconceptions about school readiness: most of the parents take into account only the well measurable, intellectual and cognitive abilities when trying to decide if their child is ready for school. Therefore, if the infant appear to be smart and shows interest about letters and numbers, they think him to be school ready without considering other critical factors such as ability for integration of a community, failure tolerance, or the capability for adapting to basic rules [3].

It may cause further misunderstandings, that according to the regulations about compulsory education, came into force in 2013 (Act CXC of 2011 on National Public Education) "children are said to be of school age in the calendar year when they turn six years of age by 31st August".

${ }^{1}$ ICT: "Information and Communication Technologies are tools, technologies, organizational activities, and innovative processes that promote, make faster, easier and more effective the communication, processing, flow, storage, and encoding of information" [2]. 
However, it is also included in the law, that "a child for whom it is recommended, on the basis of the expert opinion of a committee of experts, to stay in pre-school for one more year, shall be involved in pre-school education for another year and become of school age subsequently" [4].

According to Hungarian legal regulation, the decision about a child is being school ready should be based on the judgment of the kindergarten director, which must be in accordance with the National core curriculum for preschool education (Decree of Government 363/2012. XII. 17.). In controversial cases it is also possible for the parents to ask for an opinion of a committee of experts [5].

The conditions necessary for admission to the school can be divided into 3 main groups: physical, psychological and social factors [6].

- Physical maturity can be defined as follows: child has reached a certain development level, his body proportions have changed and shedding of primary teeth has began. The child is capable to control his movement, behavior and satisfaction of his physical needs.

- A child is school ready in psychological terms, if he is intellectual curios and open for new knowledge, and he has all the necessary abilities for starting learning at school: visual, acoustical perception and spatial orientation has reached a higher degree of differentiation. He is able to consciously memorize things and recall memories. Furthermore, executive attention, which is a prerequisite for learning and basic abstract thinking also emerge. In addition, a psychologically school ready child is able to express his thoughts and emotions in a comprehensible form and has basic knowledge about himself and his environment.

- $\quad$ By the end of kindergarten children reach the level of social maturity for starting to learn in school. It means, they are capable to cooperate with their classmates and their teachers and are able to adapt to an increasing number of rules. They also have developed the skills they need to understand and solve tasks.

PACEY is the Professional Association for Childcare and Early Years. It is a Great-Britannian charity dedicated organization which is formed with the purpose to support everyone working in childcare and early years to provide high quality care and early learning for children and families. According to the findings of PACEY's survey among childcare professionals, parents and primary school teachers, school readiness can be described with the following key factors [7]:

- school ready children are relative independent in their own personal care,

- they are curious about the world and they have a desire to learn,

- they can cope with emotionally with being separated from their parents,

- they have strong social skills.

Confidence, curiosity and relative independence are more important than cognitive and scientific skills (such as reading or counting) in early years education. According to the opinion of most childcare professionals and teachers, on playing needed to be greater emphasis in kindergarten. Research has shown that play supports chil- dren's creativity, and their emotional and social development the best [8].

The survey of PACEY [7] highlights that there are not enough focus on play in kindergartens in England, and this fact may lead to moving further away from countries like Finland which are internationally recognized for its approaches used in early years education. Tough the main purpose of England's Early Years Foundation Stage (EYFS) it to support play based education in early years, according to PACEY's survey, there is still a concern of being the focus on play eroded.

In Finland children start school at the age of 7. The preceding year of compulsory education the 6 year olds attend pre-primary schools, where instead of focusing on improving lexical knowledge, the emphasis is on playful learning, free discovering and interacting with other people. Furthermore children taking responsibility for their own actions and to take into account their peers are also key factors. Each of these kind of institutes have selfpolicies developed on the basis of the National Curriculum Guidelines on Early Childhood Education and Care in Finland (ECEC) published in 2003 [9].

E-learning and the use of ICT tools in public education are already in practice in Finland [10]. For instance, Innofactor Skilli is an application that supports learning by making for students and their teachers possible to create new goals and to monitor the already reached skills [11] (see Figure 1.). Other educational applications which are also used in public education are 10Monkeys for practicing math examples [12] (see Figure 2.), and Muuvit to help integrating the physical activity into school everyday life [13] (see Figure 3.).

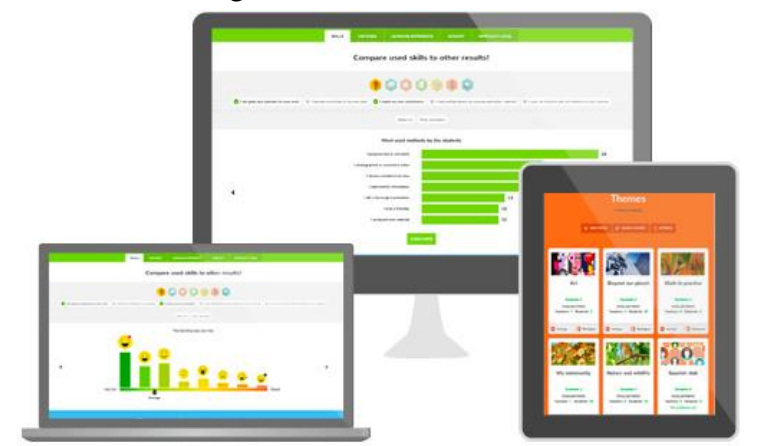

Figure 1. The Finnish Innofactor Skilli is an application that supports learning by making for students and their teachers possible to create new goals and to monitor the already reached skills. It is available both on PC, tablet and mobile phone [11].

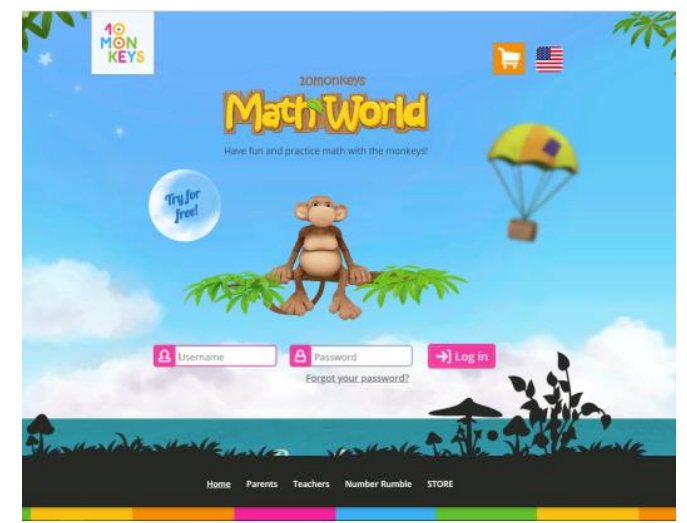

Figure 2. The main screen of the 10Monkeys app for 1-4 year olds to practice math [12] 


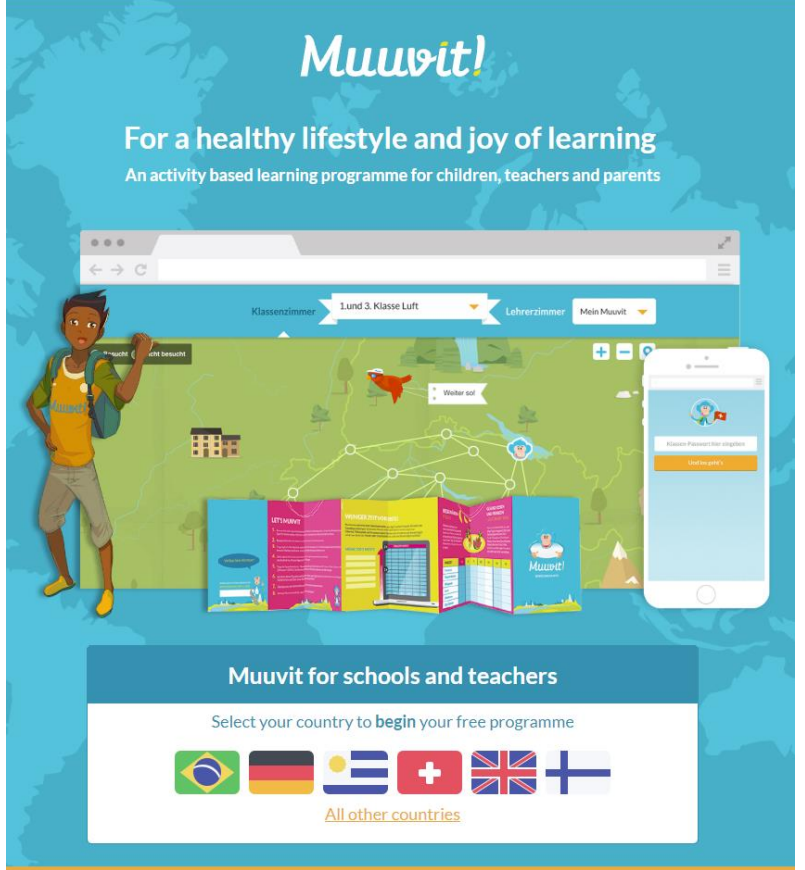

Figure 3. The Muuvit app is used by finnish students to integrate physical activity into everyday life [13].

\section{ICT TOOLS IN PUBLIC EDUCATION - IN HUNGARY AND ABROAD}

Numerous programs have been set up in foreign countries for supporting the development of educational computer and mobile applications. Furthermore the number of countries where ICT tools are provided by the government education is increasing. Due to the Digital Wellbeing Program [14] it is possible in the near future to embed technology and digital learning tools in government education in Hungary as well.

The Digital Wellbeing Program emphasizes the need for adequate infrastructure to introduce early childhood IT education in kindergartens, with particular reference to wireless internet access. Childcare professionals also needed to be trained on the methodic of integration digital technology into education. The National Core Curriculum for Preschool Education needs to be revised based on the good practices of IT education in Hungary and abroad, as this document does not address the emergence of digital assets or the challenges of the information society.

It is a priority to take advantage of children only watches at verified content on their computer screen and mobile applications both at home and in educational institutes. The behavior of the childcare professionals is critical because pattern-based behaviors, acquired in childhood, have a great influence on the child's development and consciousness.

Several governments are currently implementing their ICT policies for early childhood education, therefore the UNESCO also developed its own guidelines (ICTs in Early Childhood Care and Education [15]) in this field. The main purpose of this document is to describe the process of integration of ICT into early education and identify the possible risks and its remedies that are needed to be taken into consideration. Similarly to the Hungarian Digital Wellbeing Program, the UNESCO also highlights as highest priority to focus on the appropriate professional development of early childcare education teachers.

For kindergarten children ICT tools can provide support in education in the following areas: communication and cooperation, developing cognitive skills, creativity, social skills, educating on learning practices.

\section{THE OPPORTUNITIES OF SKILL DEVELOPMENT SUPPORTED BY MOBILE APPLICATIONS}

This chapter introduces some examples of playful applications with the purpose of supporting pre-schoolers skill development [16]. The examples are classified into the following main categories:

- Teaching of colors and shapes

- Recognizing the whole and a part of a thing

- Identify objects, organisms in the environment and associate related concepts

- Recognizing similar and different objects

- Spatial orientation, awareness of directions

- Developing speech and rhythm sense

- Logic games and problem solving

- Memory games

- $\quad$ Letters, numbers and sounds

Despite of these, these developing motion and motor skills are present in almost all examples.

The Balloon Pop Kid Learning Game an English speaking mobile application, recommended for the age groups between 2-6. It is pay free downloadable, and teaches the letters of the Alphabet, numbers, sounds (for instance the sounds of animals, music instruments, vehicles). In this game, children have to pop balloons decorated with different symbols and colors on the touch screen. While doing this, the meaning of the different symbols are being introduced by sound effects. (For example when popping a balloon decorated with a figure of the shape of a horse head neighing is being played (see Figure 4.) [17].

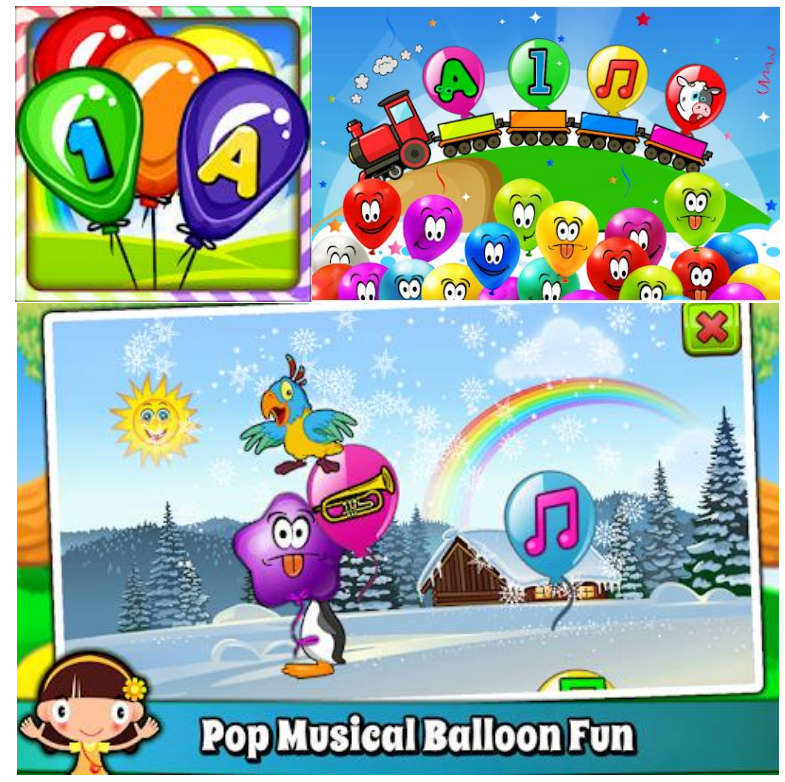

Figure 4. Screen photos of Balloon Pop Kid Learning Game [17] 
“Dino Tim” Preschool basic skills, numbers \& shapes offers exercises for children between 6-8 year in different difficulty levels to teach shapes and numbers. The default language is English, but it is also available in French, Spanish and Italian. Figure 5 shows screen photos of this application of use [18].

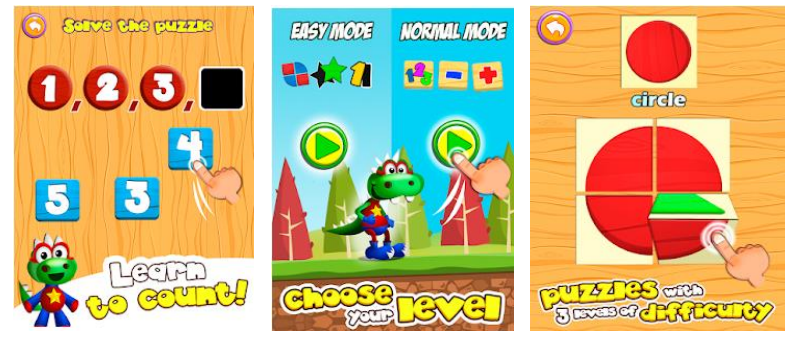

Figure 5. Screen photos of the "Dino Tim" Preschool basic skills, numbers \& shapes [18]

Hippo Kids Games is a game series. Hippo hippos is a familiar character, could be found in each member of the series. He introduces the meaning of objects and creatures of the game world to the children by interesting challenges. For instance he is asking the player's help to find stickers for his album, which are hidden in the current game environment. (see Figure 6) [19].

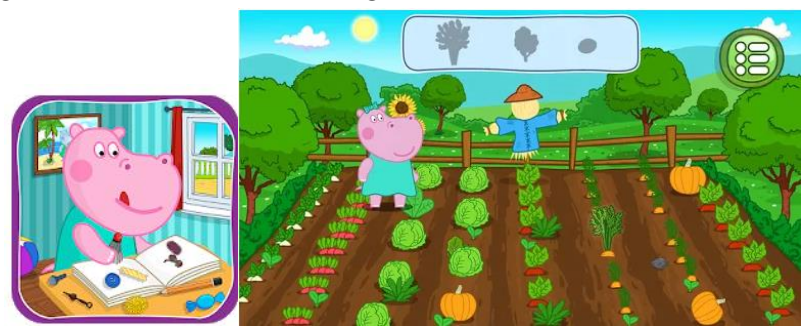

Figure 6. Screen photos of a Hippo Kids Games game series [19]

The Tangram jigsaw puzzle is popular among kids also in the form of a mobile app. It is an ancient Chinese game, where 7 different shapes ( 2 small, 1 medium, 2 large three-angle, 1 square, 1 quadrilateral) should be placed side by side to lay out different shapes (human figures, buildings, animals or symmetrical shapes or objects) (see Figure 8.)[16].
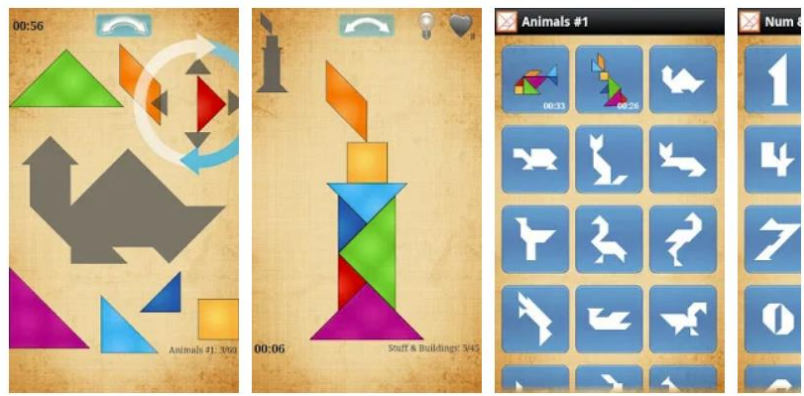

Figure 7. Screen photos of Tangaram [20]

ScrachJr introduces children to algorithmic thinking from the age of 5 and provides the basis for future programming skills. It enables young children to create their own interactive stories and games by using graphical program blocks [21]. This game is useful to play even if the player is not going to study program writing in later ages, because learning a program language helps developing creativity and problem solving skills, which are useful with later studies in every area (see Figure 8.) [27].

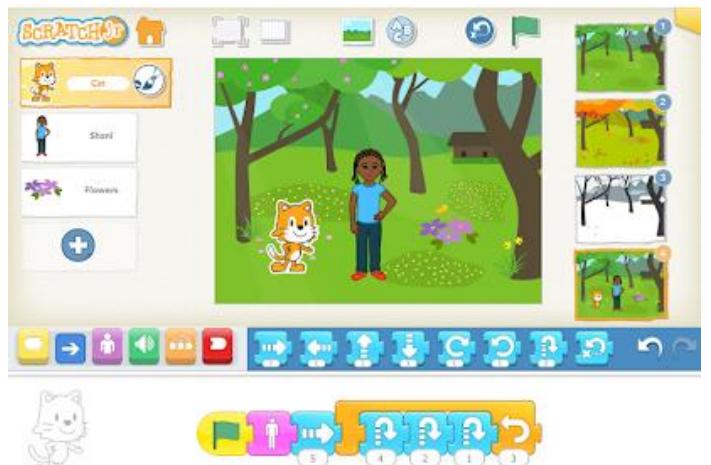

Figure 8. Screen photo of ScrachJr [21]

Educational Games for Kids is a website developed by Toy Theater, which offers interactive online games for a wide range of age groups, included kindergarten. The games on this site are categorized into 6 main categories, and each category has subcategories aswell (see Figure 9.) [22].

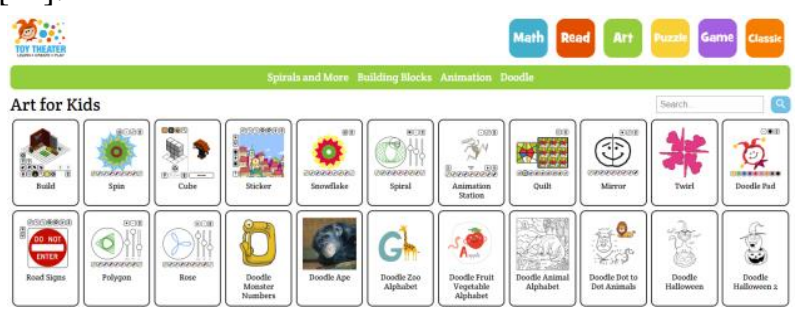

Figure 9. Toy Theater's website Educational Games for Kids offers interactive games online [22].

The Quiver-3D Coloring App is a virtual reality application. It combines the traditional coloring kid play with the features of digital technology: children's drawings "are coming to life", realistic 3D graphics animations can be watched. To use this application, colored and printed out images are necessary. By the camera of a tablet or a mobile device the printed images have to be scanned and imported to the Quiver app. Then it "brings them to life". (see Figure 10.) [23].

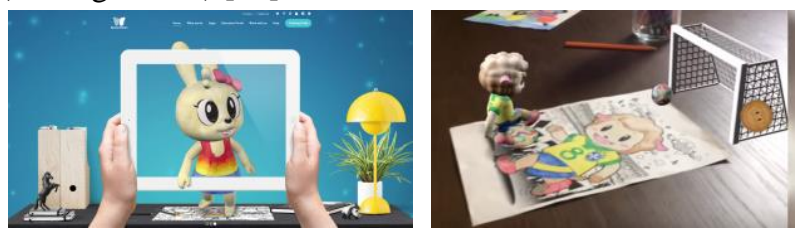

Figure 10. Screens of Quiver-3D Coloring in use [23]

Da Vinci Kids, is an award winner game, which is developed by Hungarians. This application helps kids to learn in school by watching scientific short films. So they could learn a lot of things about the field of sciences on a playful way (see Figure 11.) [24].

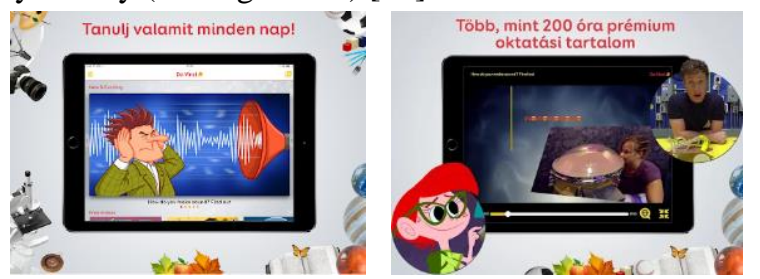

Figure 11. Screen photos of Da Vinci Kids [24] 
The Clock Learning For Kids is an educational game, recommended for 5-9 year olds. It is available in Hungarian and contains 7 lectures of which only 3 are charge free downloadable (see Figure 12.) [25].

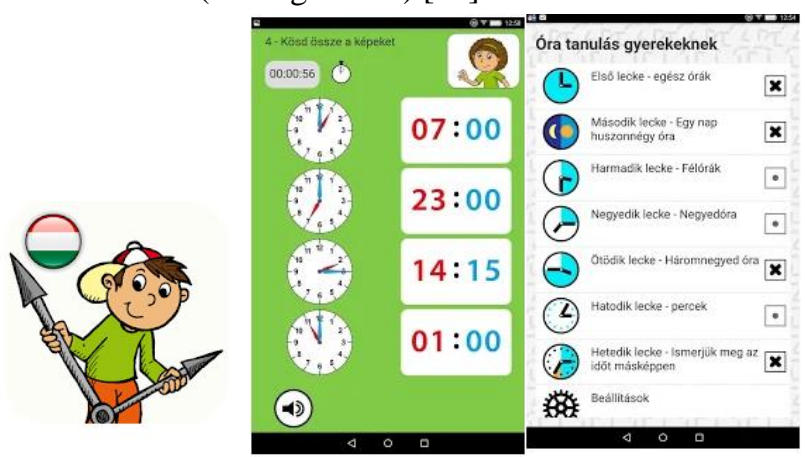

Figure 12. The logo of Clock LearningFor Kids (on the left) and screens [25]

\section{SUMMARY}

The number of computer and mobile applications available in Hungarian is very low, there is a need for further development. For kindergarten age group it is a priority that the applications are in Hungarian also speak and communicate with the kids, because in this age group there is usually a lack of reading and writing skills.

Playing on PC and mobile devices, besides developing skills toddlers can learn about Hungarian cultures, such as folktales, nursery rhymes, native plants and animals, embedded into frame stories.

\section{REFERENCES}

[1] A. Morin, "How Kids Develop Thinking and Learning Skills", Visited: 2018.04.10.

[2] K. Körmöci, “A játék tudatos felhasználása a tanulásban”, Kisgyermeknevelés, vol 4., issue 4., pp. 2-9.

[3] É. Deliágia, "9 kérdésés kiderül, mejen-e idéniskolába a gyerek", 2017.02.15.

http://hvg.hu/pszichologiamagazin/20170205_9_kerdes_es_kider ul menjene iden iskolaba a gyerek. Visited: 2018.04.10.

[4] Magyar Országgyülés, 2011. évi CXC. törvény a nemzetiköznevelésröl, 45. § (2) bekezdés, Magyar Közlöny, https://net.jogtar.hu/jogszabaly?docid=A1100190.TV, 2011. Visited: 2018.04.10.

[5] EMMI, 20/2012. (VIII. 31.)EMMI rendelet a tankötelezettségmegállapításáról, 21.§ (1) - (3) bekezdés, Magyar Közlöny, https://net.jogtar.hu/jogszabaly?docid=a1200020.emm, 2012. Visited: 2018.04.10

[6] Magyar Kormány, 363/2012. (VII. 17.) Korm. rendeletazÓvodainevelésországosalapprogramjáról, 1. melléklet, VI. (1)-(5), https://net.jogtar.hu/jogszabaly?docid=a1200363.kor, 2012. Visited: 2018.04.10.

[7] "What Does "School Ready" Really Main? A research report from", Professional Association for Childcare and EarlyYears , Royal Court, 81 Tweedy Road, Bromley, Kent. https://www.pacey.org.uk/SSTMicrosite/media/Website-Files-
SST/school\%20ready/School-Ready-Report.pdf, 2013.Visited: 2018.04.10.

[8] L. Ksik, "A szociális kompetencia fejlesztésének elmélete és gyakorlata”, Iskolakultúra, vol 1., 11-12, pp. 21-37, 2007.

[9] National Cirrumculum Guidelines on Early Childhood Education and Care in Finnland, https://www.julkari.fi/bitstream/handle/10024/75535/267671cb0ec0-4039-b97b-7ac6ce6b9c10.pdf?sequence=1\&isAllowed=y, Helsinki: STAKES, 2003, p. 40. Visited: 2018.04.10.

[10] Finnish Excellence in Education, http://www.eduexport.fi/documents/85622/107866/Finnish+Exce lence+in+Education/6d02d1b2-5b9e-4ad4-adb5-c175e149cdca, p. 16., Visited: 2018.04.10.

[11] InnofactorSkilli, "Skilli”, Innofactor, http://www.skilli.com/en/. Visited: 2018.04.10.

[12] “10Monkeys", https://www.10monkeys.com/us/. Visited: 2018.04.10.

[13] Muuvit Health \& Learning Oy Ltd., "Muuvit", https://www.muuvit.com/. Visited: 2018.04.10.

[14] Digitális Jólét Program, Magyarország Digitális OktatásiStratégiája, Budapest.

http://www.kormany.hu/download/0/cc/d0000/MDO.pdf, Magyar Kormány, 2016, p. 157. Visited: 2018.04.10.

[15] UNESCO Institute for Information Technologies in Education, ICTs and early childhood learning, https://iite.unesco.org/pics/publications/en/files/3214720.pdf, 2012, p. 12. Visited: 2018.04.10.

[16] S. Szabó, Látogatás a tudásbirodalmába, Budapest: Pirkadat, 2013, 2017, p. 156. ISBN: 9789631288964

[17] G. Gunjan, Balloon Pop Kids Learning Game, https://www.amazon.com/Balloon-Pop-Kids-LearningGame/dp/B01LIF37H8.Visited: 2018.04.10.

[18] Dino Tim, "'Dino Tim" Preschool basic skills, numbers \& shapes", https://dinotim.com/. Visited: 2018.04.10.

[19] "Hippo Kids Games", https://play.google.com/store/apps/developer?id=Hippo+Kids $+\mathrm{G}$ ames\&hl=hu. Visited: 2018.04.10.

[20] "Tangram",

https://play.google.com/store/apps/details?id=com.jin.games.tang ram\&hl=en_US. Visited: 2018.04.10.

[21] DevTech Research Group at Tufts University; Lifelong Kindergarten Group at the MIT Media Lab; Playful Invention Company, https://www.scratchjr.org/, https://www.scratchjr.org/. Visited: 2018.04.10.

[22] Toy Theater, "Educational Games for Kids", http://toytheater.com/.Visited: 2018.04.10.

[23] QUIVERVISION, "Quiver - 3D Coloring App", http://www.quivervision.com/. Visited: 2018.04.10.

[24] "Da Vinci Kids - oktatóvideó streaming", https://play.google.com/store/apps/details?id=com.alegra.kidspac e\&hl=hu. Visited: 2018.04.10.

[25] PMQ Software, "Óra tanulását segítő oktatójéték", http://www.pmq-software.com/sw/hu/ora-tanulasgyerekeknek/.Visited: 2018.04.10.

[26] Carla, "The Preschooler's Brain: How Young Children Learn", 14 06 2014. http://preschoolpowolpackets.blogspot.hu/2014/08/thepreschoolers-brain-how-young.html. Visited: 2018.04.10.

[27] Emberi Erőforrások Minisztériuma, ,20/2012. (VIII. 31.)EMMI rendelet a tankötelezettség megállapításáról”, p. 21. §. 